\title{
Results of hysteroscopic management of endometrial pathology through laser diode in naval medical center: number of cases
}

\author{
Yanet Fermin Aldama ${ }^{1 *}$, Cesar Rodriguez Villán ${ }^{2}$, Sara E. Hernández Flores ${ }^{3}$
}

\author{
${ }^{1}$ Department of Obstetrics and Gynecology, Naval Medical Center, Mexico City, México \\ ${ }^{2}$ Affiliated Physician, Naval Medical Center, Mexico City, México \\ ${ }^{3}$ Chief of Tococirugia, Naval Medical Center, Mexico City, México
}

Received: 09 October 2019

Revised: 01 February 2020

Accepted: 06 February 2020

\section{*Correspondence:}

Dr. Yanet Fermin Aldama,

E-mail: yanet_aldama@hotmail.com

Copyright: ( ) the author(s), publisher and licensee Medip Academy. This is an open-access article distributed under the terms of the Creative Commons Attribution Non-Commercial License, which permits unrestricted non-commercial use, distribution, and reproduction in any medium, provided the original work is properly cited.

\begin{abstract}
Background: Hysteroscopy consists of an excellent technique for the diagnosis of uterine pathology, the diode laser for treatment has been included, which is energy in the form of a beam of light, monochromatic and coherent, equipped with a great capacity to cut tissues and vaporize them. Objective of this study was to know the result of the hysteroscopic treatment with diode laser, in patients of reproductive age with uterine pathology in the naval medical center of Mexico for a period of one year.

Methods: A descriptive study was carried out in 8 patients, with abnormal uterine bleeding and uterine pathology, to know the result of the hysteroscopic treatment with diode laser, inclusion criteria were age of 18 to 40 years, uterine pathology, without previous treatments, exclusion criteria were pregnancy, medical treatment, does not accept the procedure, in a period of September 1, 2017 and September 1, 2018 at the Naval Medical Center of Mexico, the 45watt $980 \mathrm{~nm}$ and 1470 wavelength diode laser console $\mathrm{nm}$ with $3 \mathrm{fr}$ extra flexible conical tip glass fibers.

Results: The average age $29.9 \pm 8.5$ years, without comorbidities; $60 \%$ had an initial diagnosis of endometrial thickening and abnormal uterine bleeding and $40 \%$ had a diagnosis of infertility, the most frequent pathology is an endometrial polyp, during the procedure none of the patients required analgesia or post-surgical sedation. The average bleeding was $24.44 \mathrm{ml}$.

Conclusions: The hysteroscopic removal of uterine pathology with diode laser was performed without anesthesia, in an outpatient, feasible and safe way, the surgical time is reduced, with a follow-up of 12 months without recurrence.
\end{abstract}

Keywords: Abnormal uterine bleeding, Diode laser, Endometrial pathology, Hysteroscopy, Outpatient, Polyp

\section{INTRODUCTION}

Menstrual disorders are a common indication of a medical visit among women of reproductive age, menstrual abnormalities affect up to $30 \%$ of women throughout their lives. ${ }^{1,2}$ The prevalence in the extremes of reproductive age increased, being the highest among adolescents who have just experienced menarche and women in years of perimenopause. ${ }^{3}$ It is defined as abnormal uterine bleeding to the variation of the normal menstrual cycle, and includes changes in the regularity, cycle frequency, and duration of the flow or in the amount of menstrual bleeding different diagnostic methods are adopted, and hysteroscopy is introduced flexible as an additional tool to investigate uterine pathology. ${ }^{2-5}$ Since it is a minimally invasive procedure that has proven to be highly accurate in the diagnosis of abnormalities of the uterine cavity. ${ }^{4,6,7}$ Flexible hysteroscopes have offered evaluation of abnormal uterine bleeding. ${ }^{8}$ In the outpatient setting, due to its 
greater tolerability, safety, uterine pathology depending on the location of the anatomical involvement. ${ }^{9}$ The most frequent are endometrial polyps. ${ }^{10}$ Endometrial polyps represent an overgrowth located in the endometrium that projects over the epithelium, the prevalence in the population is approximately $10-30 \%$ in women with abnormal uterine bleeding. ${ }^{11}$ Therefore, during the course of time several treatments have been included in order to reduce recurrences of uterine pathology, among them the diode laser. ${ }^{11}$ Achieves high absorption simultaneously by water and predominantly by haemoglobin. ${ }^{12}$ Which provides its hemostatic properties, thus postulating a high capacity for ablation and vaporization, reducing the recurrence of pathology. ${ }^{12}$

\section{METHODS}

In this work, a descriptive study was conducted in the gynecology and obstetrics department of the Naval Medical Center of Mexico for a period of one year (September 2017 to September 2018). This study was made up of 8 women of reproductive age (21 to 41 years old), who accepted the terms of the informed consent that contained the following criteria.

\section{Inclusion criteria}

- Reproductive age between 21 and 41 years of age

- Prior diagnostic histeroscopy

- Abnormal uterine bleeding

- Infertility

\section{Exclusion criteria}

- Patients whit comorbidities

- Previous treatment of endometrial pathology

- Nubile patients

- Dysfunctional uterine bleeding
Afterwards, the corresponding diagnostic hysteroscopy and reached a diagnosis of uterine pathology. Patients who required surgical hysteroscopy were informed; therapeutic hysteroscopy was performed using a rigid 5 $\mathrm{mm}$ hysteroscope; the technique was carried out following the Bettochi model where, for the exeresis of polyps, myomas and septa, a diode laser console whit a wavelength of $980 \mathrm{~nm}$ and $1470 \mathrm{~nm}$ was used, the techniques were performed: at a distance, which allows maximum diffusion of coagulation in the absence of cut and contact, this allows the destruction of the tissue when touched with a depth between 5 and $7 \mathrm{~mm}$. it should be noted that the patients did not receive pre-medication, nor the use of anesthesia and showed no complications after the procedure. It should also be mentioned that no other therapeutic procedure was required so far.

\section{RESULTS}

\section{Obstetric diagnosis}

The age of the 8 patients who participated in this study is observed, with an average ( \pm standard deviation) of $30.9 \pm 7.8$ years (Table 1) As well as, the most frequent symptom by which they went to gynecological consultation was the abnormal uterine bleeding and the initial diagnosis with greater prevalence was: hyperpolymenorrhea whit $25 \%$. However, $38 \%$ of patients are infertile (Figure 1).

\section{Treatment}

On the other hand, the average duration of surgery was 26.6 minutes with a range between 20 and 50 minutes. In addition, none of the patients required analgesia or postsurgical sedation. Also, an average bleeding of $24 \mathrm{ml}$ was observed. Likewise, $87.5 \%$ of the patients received hysterescopy treatment with the therapy and $12.5 \%$ hysterescopy with oppium technique (Figure 2).

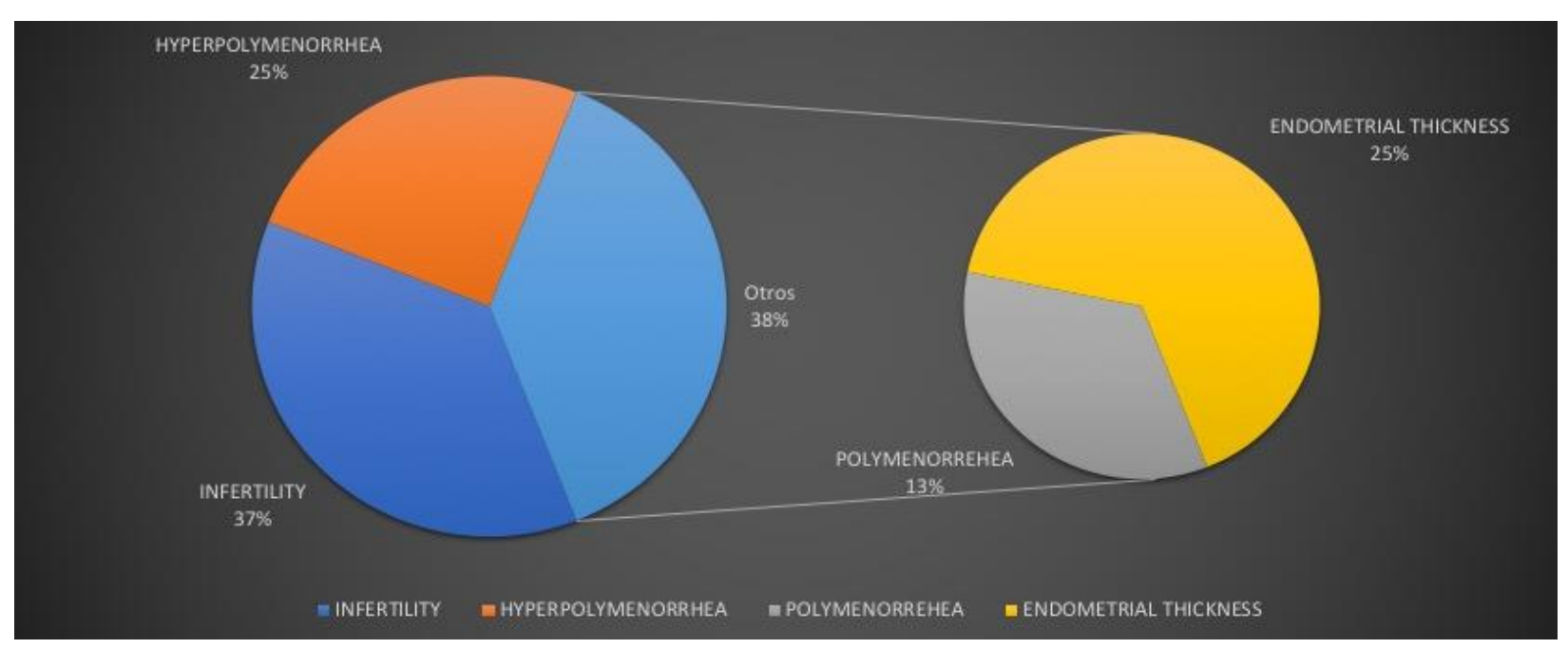

Figure 1: Initial diagnostic. 


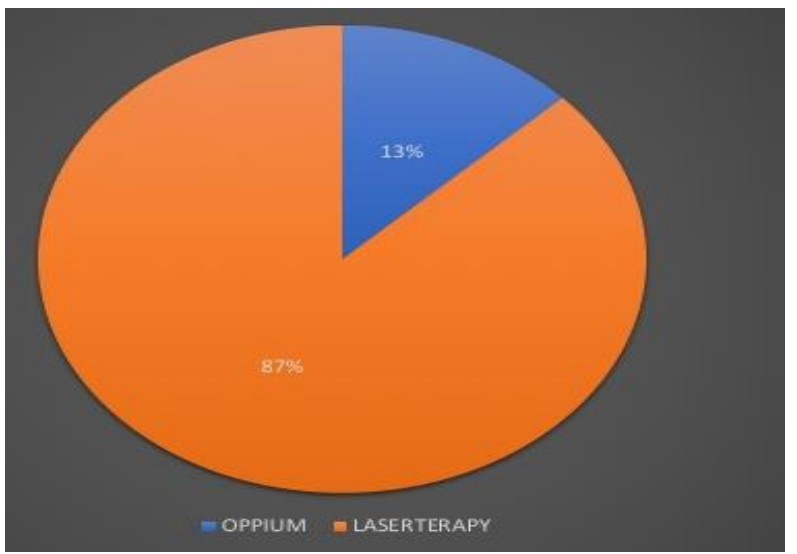

Figure 2: Treatment.
The initial diagnoses abnormal uterine bleeding was the most frequent symptom for which they go to gynecological consultation, with hyperpolymenorrhea $(25 \%)$ being more prevalent, however infertility (38\%). The average surgery time was 26.6 minutes with a range between 20 and 50 minutes; None of the patients required analgesia or post-surgical sedation (Figure 1).

The average bleeding was $24 \mathrm{ml}$. The treatment implemented in the patients was: hysteroscopy + laser therapy in $87.5 \%$ (7 patients), hysteroscopy oppium technique in $12.5 \%$ (1 patient), as shown in Figure 2.

The average age of the 5 normoregulated/no anemic syndrome data is $30 \pm 8.2$ years; two normoregladas the average age is $37 \pm 4.2$ years, and 1 pregnant patient after treatment.

Table 1: Sample description.

\begin{tabular}{|c|c|c|c|c|}
\hline Number & Age & Shipping diagnosis & Echography & Diagnostic hysteroscopy \\
\hline 1 & 40 & $\begin{array}{l}\text { Endometrial } \\
\text { polyposis }\end{array}$ & $\begin{array}{l}\text { No evidence of occupant } \\
\text { injuries }\end{array}$ & $80 \%$ uterine anterior polyp \\
\hline 2 & 41 & $\begin{array}{l}\text { Thickening } \\
\text { endometrial }\end{array}$ & $20 \mathrm{~mm}$ endometry & $\begin{array}{l}\text { Endometry polyps in previous right face, } \\
\text { approx } 10 \mathrm{~mm} \text {, mioma type } 0 \text { in fund }\end{array}$ \\
\hline 3 & 36 & Hyperpolymenorrhea & Suggestive polip image & $\begin{array}{l}\text { Pediculated faces in the face of } 10 \mathrm{~mm} \\
\text { occupying } 20 \% \text { of the endometrial cavity }\end{array}$ \\
\hline 4 & 34 & Infertility & Suggestive polip image & $\begin{array}{l}\text { Polyp in the whole cavity, greater in the } \\
\text { face after } 80 \% \text {. }\end{array}$ \\
\hline 5 & 27 & $\begin{array}{l}\text { Thickening } \\
\text { endometrial }\end{array}$ & $21 \mathrm{~mm}$ endometry & $\begin{array}{l}\text { Polyp of } 3 \times 2.5 \mathrm{~cm} \text { that occupies } 80 \% \\
\text { anchored to left poster-lateral face }\end{array}$ \\
\hline 6 & 25 & Infertility & $\begin{array}{l}\text { Utero bicorne with sept of } 2 \mathrm{~cm} \\
\text { with predominant right cavity }\end{array}$ & $\begin{array}{l}\text { Uterine sept which covers } 70 \% \text { of the } \\
\text { cavity }\end{array}$ \\
\hline 7 & 23 & Polymenorrea & Mioma submucoso versus polyp & Mioma $1.5 \times 2 \mathrm{~cm}$ in back face. \\
\hline 8 & 21 & Hyperpolimenorrea & Thickening endometrial & $\begin{array}{l}50 \% \text { polyposis in the previous face of the } \\
\text { uterus }\end{array}$ \\
\hline
\end{tabular}

None present recurrence of uterine pathology.

\section{DISCUSSION}

Currently, he main indication or diagnostic hysterosocopy is abnormal uterine hemorrhage, which is multifactorial and may be due to various disorders such as: endometrial atrophy, polyps and hyperplasia1. In this study, polyps were the most frequent ultrasound indication.

On the other hand, it has been described that hysterosocopy shows good results without the use of anesthesia, because a great tolerance has been observed in patients, which reduces risks and costs. ${ }^{3,4}$ It should also be mentioned that this reduces complications related to the use of anesthesia; it should be noted that these advantages provided by hysteroscopic treatment were observed in patients who underwent our study.
In studies in women with uterine pathologies, an average age between 44 and 47 years was observed. ${ }^{11-12}$ However, in this work the average age of our patients was 30 years.

In this work, it was observed that the laser acts selectively on the affected area that is to be treated with minimal damage to adjacent tissue; this reduces the side effects related to the destruction of healthy tissue and its surroundings, causing less inflammation.

Regarding this procedure, it should be mentioned that it is recently used in our unit. This is why the number of patients treated with ambulatory laser hysteroscopy is limited. In addition, we can suggest the following advantages of this technique: outpatient resection without admission. Decreased use of general or spinal anesthesia, immediate recovery of the patient and better management of the operating rooms. Therefore, all these advantages contribute to improve the efficiency of hysteroscopy and 
the quality of care provided to patients who develop uterine pathologies. ${ }^{12}$

Funding: No funding sources

Conflict of interest: None declared

Ethical approval: Not required

\section{REFERENCES}

1. Vázquez Rodríguez M, Pablo Mosquera M, García García M. Hysteroscopic findings in postmenopausal patients in the university hospital complex of Ourense. Clinic Res Gynecol Obstet. 2015;42:3.

2. Chuong CJ, Brenner PF. Management of abnormal uterine bleeding. Am J Obstet Gynecol. 1996;175(3):787-92.

3. Singh S, Best C, Dunn S, Leyland N, Wolfman WL, Wolfman W, et al. Abnormal uterine bleeding in premenopausal women. J Obstet Gynaecol Can. 2013;35(5):473-9.

4. Zhang J, Shi W. Treatment of adenomyosis by hysteroscopy. J Minimally Inv Gynecol. 2015;22(6):S123.

5. Levie M, Chudnoff S. Endometrial pipelle biopsy identifying a polyp versus office hysteroscopy. J Minimally Inv Gynecol. 2015;22(6):S109.

6. DeCherney AH, Nathan L. Current diagnosis and treatment obstetrics and gynecology. Univerza $\mathrm{v}$ Ljubljani, Medicinska fakulteta; 2013. Available at: https://repozitorij.uni-lj.si/IzpisGradiva.php?id=501 98. Accessed on $5^{\text {th }}$ October 2019.

7. Munro MG, Critchley HO, Broder MS, Fraser IS. FIGO classification system (PALM-COEIN) for causes of abnormal uterine bleeding in nongravid women of reproductive age. Int $\mathbf{J}$ Gynaecol Obstet. 2011;113(1):3-13.

8. Haimovich S. Laser in office hysteroscopy. Mastering the Techniques in Hysteroscopy. 2017:157.

9. Singh S, Best C, Dunn S, Leyland N, Wolfman WL, Wolfman W, et al. Abnormal uterine bleeding in premenopausal women. J Obstet Gynaecol Canada. 2013;35(5):473-5.

10. Haimovich S, López-Yarto $\mathrm{M}$, Urresta Ávila J, Saavedra Tascón A, Hernández JL, Carreras Collado, R. Office hysteroscopic laser enucleation of submucous myomas without mass extraction: a case series study. BioMed Res Int. 2015:2015.

11. Moawad NS, Santamaria E, Johnson M, Shuster J. Cost-effectiveness of office hysteroscopy for abnormal uterine bleeding. J Society Laparoendoscopic Surg. 2014;18(3):e2014.00393.

12. Lara-Domínguez MD, Arjona-Berral JE, DiosPalomares R, Castelo-Branco C. Outpatient hysteroscopic polypectomy: bipolar energy system (Versapoint ${ }^{\circledR)}$ versus diode laser-randomized clinical trial. Gynecol Endocrinol. 2016;32(3):196200.

Cite this article as: Fermin Aldama Y, Rodriguez Villán C, Hernández Flores SE. Results of hysteroscopic management of endometrial pathology through laser diode in naval medical center: number of cases. Int J Reprod Contracept Obstet Gynecol 2020;9:918-21. 